\title{
Clinical Efficacy on the Use of Titanium Intramedullary Interlocking Nailing (Ti- IILN) for Repair of Communited Diaphyseal Femur Fractures in Dogs
}

\author{
Jagan Mohan Reddy $\mathrm{K}^{1 *}$ and Dilip Kumar $\mathrm{D}^{2}$ \\ Department of Veterinary Surgery and Radiology, Veterinary College, Bidar, KVAFSU, Karnataka, INDIA \\ *Corresponding Author: JMK Reddy; E-mail: drvetjagan@gmail.com
}

Received: 27 Aug., 2021

Revised: 12 Sept., 2021

Accepted: 11 Sept., 2021

\begin{abstract}
The study was conducted in dogs with comminuted diaphyseal fractures of femur. The dogs were stabilized with titanium IILN of diameter $5 \mathrm{~mm}, 6 \mathrm{~mm}$ and $8 \mathrm{~mm}$ were used. The length of nails used $140 \mathrm{~mm}, 160 \mathrm{~mm}$ and $180 \mathrm{~mm}$. Good implant stability and remarkable improvement with normal limb function except bolt loosening and bolt breakage two dogs. All dogs showed weight bearing of the affected limb while walking from $3^{\text {rd }}$ day in 3 dogs, $10^{\text {th }}$ day in 2 dogs, $15^{\text {th }}$ day in 2 dogs, $30^{\text {th }}$ day in one dog post-operatively. The mean lameness grades pre-operatively and on $1^{\text {st }}$ day, $15^{\text {th }}$ day, $30^{\text {th }}$ day, $60^{\text {th }}$ day and $90^{\text {th }}$ day post- operatively were found to be $5.00 \pm 0.00,3.25 \pm 0.16,2.50 \pm 0.26,1.50 \pm 0.26,1.12 \pm 0.12$ and $1.00 \pm 0.00$, respectively. The mean age of the group to bear the complete weight were seen on $11.75 \pm 3.26$ days. The radiographs on the $15^{\text {th }}$ post-operative day revealed proper apposition and alignment, on $30^{\text {th }}$ day showed evidence of callus formation, on $60^{\text {th }}$ day, 6 dogs the fracture line disappeared showing clear restitution of cortico-medullary cavity and in two dogs, bridging callus formation. On $90^{\text {th }}$, day cortico-medullary distinction at the fracture site. Based on the results, it is concluded Titanium IILN was successful in the treatment of comminuted diaphyseal femur fractures in dogs with lower rate of failure and fewer complications and offered early return of limb function, with good fracture stability till the completion of the bone healing in all dogs when compared to stainless steel IILN.
\end{abstract}

\section{HIGHLIGHTS}

(0 Titanium IILN is most suitable for comminuted diaphyseal fractures of femur in canines.

(0 Titanium IILN offered early return of limb function, with good fracture stability, and lower rate of failure.

Keywords: Titanium-Intramedullary Interlocking nail, Internal fixation, biocompatibility, femur fracture repair, dogs, titanium nails, and titanium bolts

The incidence of musculoskeletal injuries has been increasing constantly and among the small animal surgical cases the incidence of fractures was among the different species and reported it was highest in canines $(35.66 \%)$ species, and pertaining to bones it was highest in femur bone (36.59\%) (Patil et al., 2018). Pelvic limb was the most affected limb (85.2\%) among which femur bone $(29.6 \%)$ was the most commonly involved bone followed by tibia-fibula $(11.2 \%)$ in dogs (Keosengthong et al., 2019).

The goal of fracture fixation to simply decrease fracture gaps with one of two approaches to a given fracture: (1) eliminate interfragmentary strain through anatomic reconstruction, compression of bone ends with rigid fixation, and absolute stability (i.e., complete elimination of the fracture gap); or (2) maintain a low strain environment through bridging techniques and implants that allow relative stability (i.e., maintenance of somewhat large interfragmentary gaps). Secondary bone healing (indirect bone healing) occurs in fractures which are not anatomically reconstructed and

How to cite this article: Jagan Mohan Reddy, K. and Dilip Kumar, D. (2021). Clinical Efficacy on the Use of Titanium Intramedullary Interlocking Nailing (Ti-IILN) for Repair of Communited Diaphyseal Femur Fractures in Dogs. J. Anim. Res., 11(05): 807-817.

Source of Support: None; Conflict of Interest: None 
stabilized with rigid internal fixation heal by an organized process known as secondary bone healing. Interlocking nails, bridge or lengthening plates, and plate/rod fixation, when used to bridge large zones of comminution, provide relative stability and result in secondary bone healing. (Moreno et al., 2018).

Titanium implants compared to stainless steel were having lower susceptibility to infection due to its biocompatibility (Arens et al., 1996). Titanium and some of its alloys provide many advantages such as excellent biocompatibility, high strength-to-weight ratio, lower elastic modulus, and superior corrosion resistance, required for dental and orthopedic implants (Nouri et al., 2010). In comparison to stainless steel, titanium alloy has superior fatigue and corrosion resistance (Ferrell, 2016).

Adding to its material, titanium gives additional advantage such as excellent biocompatibility, high strength-to-weight ratio, lower elastic modulus, and superior corrosion resistance (Ferrell, 2016). Due to paucity of literature on use of Titanium IILN for fracture repair in dogs, the present study was undertaken to record the clinical efficacy of Titaniumin tramedullary interlocking nailing for repair of communited diaphyseal femoral fractures in dogs.

\section{MATERIALS AND METHODS}

\section{Anamnesis}

The dogs presented for treatment in this group were 5 Mongrel dogs, 2 German Shepherds and one Golden
Retriever. The mean age of the dogs was $7.25 \pm 1.14$ months with ranging from 4 months to 12 months. The body weights of the dogs ranged from 10 to $20 \mathrm{~kg}$ with a mean of $16.12 \pm 1.39 \mathrm{~kg}$. The cause of fractures in this group was car accident in 3 dogs, bike accidents in 3 dogs and slipped on the floor in 2 dogs. The fractures occurred in 5 male dogs and 3 female dogs. The mean time of gap between the time of fracture and treatment was $4.87 \pm 0.78$ days with a range of 2 to 8 days. The details were shown in table 1 .

\section{Pre-operative observations}

The dogs presented for treatment femur fractures exhibited symptoms like sudden onset of pain and lameness immediately after a trauma. There were symptoms like swelling, dangling of the limb, non-weight bearing and abnormal angulation of the limb at the fracture site (Fig. $1)$.

\section{Pre-operative radiographic observations}

Two plain orthogonal views of the affected limbs including the proximal and distal joints confirmed fractures (Guiot et al., 2012). The radiographs revealed comminuted mid diaphyseal closed fracture of right femur, Comminuted oblique diaphyseal fracture, oblique diaphyseal closed fracture of right femur and spiral mid diaphyseal closed fracture of right femur (Fig. $2 \mathrm{~A}$ to $\mathrm{H}$ ). The details regarding the fractures encountered in all the dogs are presented in Table 2.

Table 1: History and Signalment of the dogs selected for the study in this group

\begin{tabular}{lllllll}
\hline $\begin{array}{l}\text { Sl. } \\
\text { No. }\end{array}$ & Breed of dog & Sex & Age in months & Body weight $\mathbf{( k g )}$ & Etiology of fracture & $\begin{array}{l}\text { Days since } \\
\text { fracture }\end{array}$ \\
\hline 1 & German Shepherd & Male & 4 & 14 & Car accident & 8 \\
2 & Mongrel & Male & 8 & 18 & Car accident & 7 \\
3 & Mongrel & Female & 4 & 10 & Bike accident & 3 \\
4 & Mongrel & Female & 5 & 11 & Bike accident & 4 \\
5 & Golden Retriever & Male & 7 & 20 & Slipped on the floor & 2 \\
6 & German Shepherd & Male & 6 & 18 & Slipped on the floor & 5 \\
7 & Mongrel & Female & 12 & 18 & Bike accident & 3 \\
8 & Mongrel & Male & 12 & 20 & Car accident & 7 \\
\hline & Males-5 & $7.25 \pm 1.14$ & $16.12 \pm 1.39$ & & $4.87 \pm 0.78$ \\
\hline
\end{tabular}



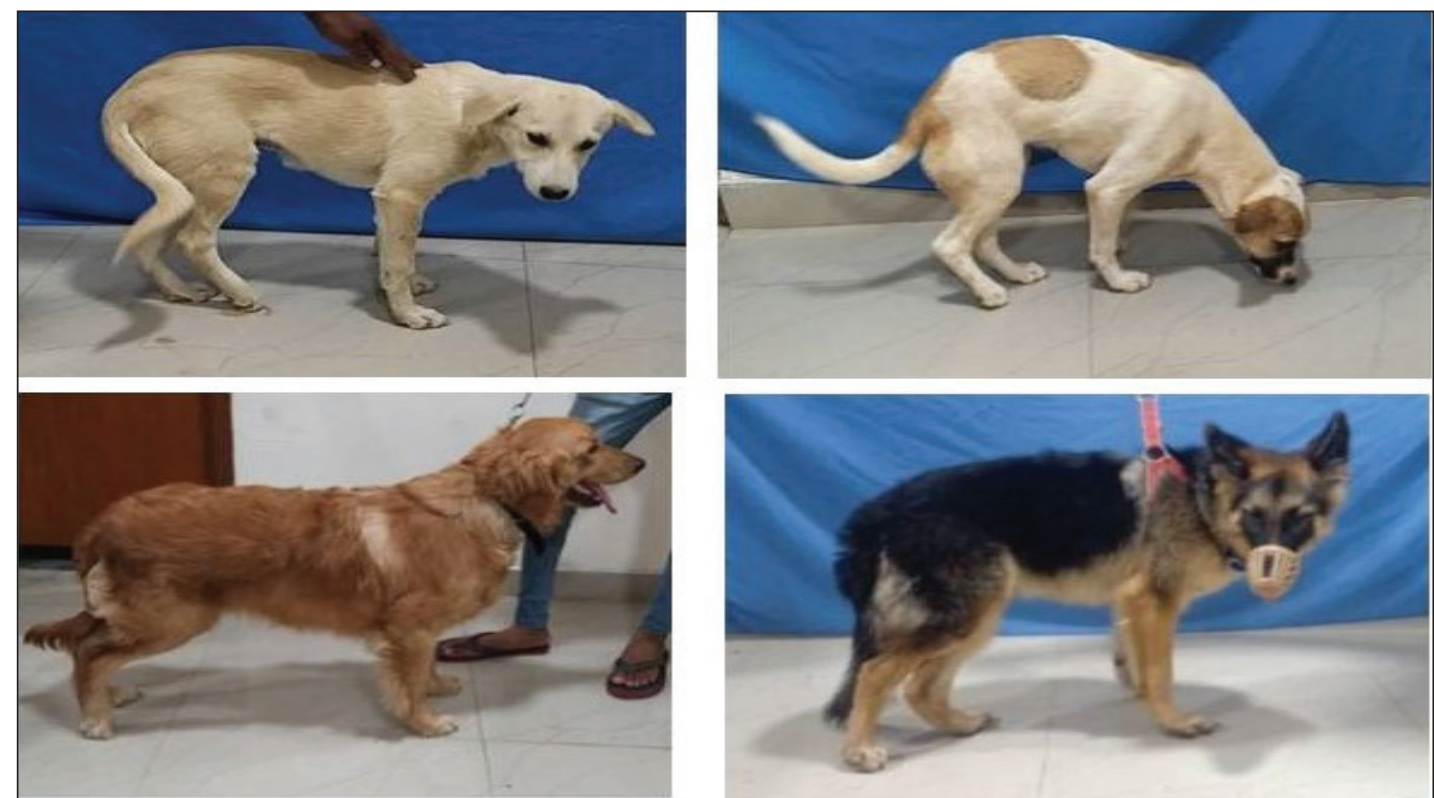

Fig. 1: Non weight bearing of the fractured limb in dogs pre-operatively

Table 2: Pre-operative Radiological Observations (Titanium intramedullary interlocking nailing)

\begin{tabular}{lllll}
\hline Case No. 1 & Limb affected & Bone involved & Open or closed & Type /Location of fracture \\
\hline 1 & Right Hind limb & Right femur & Closed & Oblique Mid diaphyseal fracture \\
2 & Right hind limb & Right femur & Closed & Spiral diaphyseal fracture \\
3 & Right Hind limb & Right femur & Closed & Comminuted diaphyseal fracture \\
4 & Right Hind limb & Right femur & Closed & Oblique diaphyseal fracture \\
5 & Right Hind limb & Right femur & Closed & Spiral diaphyseal fracture \\
6 & Right Hind limb & Right femur & Closed & Oblique diaphyseal fracture \\
7 & Right Hind limb & Right femur & Closed & Comminuted oblique diaphyseal fracture \\
8 & Right Hind limb & Right femur & Closed & Spiral diaphyseal fracture \\
\hline
\end{tabular}
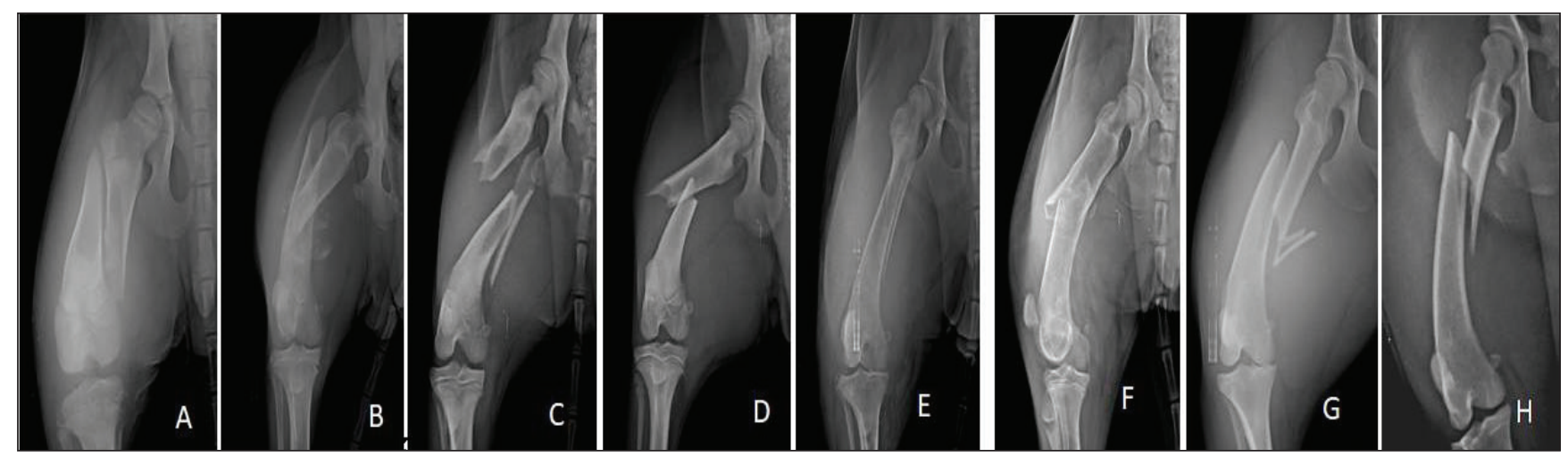

Fig. 2: Pre-operative skiagram showing fracture of femur in a dogs (cranio-caudal view)

(A) Complete diaphyseal oblique fracture, (B) Complete diaphyseal spiral fracture, (C) Complete diaphyseal comminuted fracture, (D) Complete diaphyseal oblique fracture, (E) Complete diaphyseal spiral fracture, (F) Complete diaphyseal oblique fracture, (G) Comminuted olique diaphyseal fracture, $(\mathbf{H})$ Spiral diaphyseal fracture. 


\section{Planning of surgery}

The length of the bolts needed for application of titanium IILN, in each patient was determined by measuring the medio-lateral thickness of fractured femur at different distances from the fracture site directly from the anteroposterior view and length and thickness of titanium interlocking nail was determined by measuring the mediolateral radiographs respectively (Fig. 3).

\section{Patient preparation}

The affected limb was aseptically prepared by clipping the hair from a wide area surrounding the fracture site taking care to include upper and lower joints. The operative site was shaved and scrubbed using povidone-iodine surgical scrub, followed by the application of surgical spirit. Similarly, the skin was also prepared over the cephalic vein on both fore limbs for intravenous injections. Normal saline was infused intravenously throughout the duration of surgery.

\section{Anaesthesia}

Atropine sulphate at the rate of $0.04 \mathrm{mg} / \mathrm{kg}$ body weight was administered subcutaneously as pre-anesthetic medication followed 10-15 minutes later by xylazine hydrochloride at the rate of $1 \mathrm{mg} / \mathrm{kg}$ body weight intramuscularly.
Ten minutes later, general anaesthesia was induced with intramuscular injection of ketamine hydrochloride at the rate of $10 \mathrm{mg} / \mathrm{kg}$ body weight (Fattahian et al., 2011). Anaesthesia was maintained with intravenous injection of propofol at the rate of $4 \mathrm{mg} / \mathrm{kg}$ body weight. Additional doses of propofol were also administered whenever necessary during surgical procedure through the intravenous line.

\section{Positioning of the animal}

The dogs with fracture of femur was positioned in lateral recumbency with the fractured limb up.

\section{MATERIALS}

\section{Orthopaedic instruments}

A general surgical instrument set and orthopaedic instruments were used along with the Interlocking Jig and its accessories.

\section{Implants}

The choice of implant and its size was determined on the basis of the age, weight of the dog and the diameter of the bone as measured from the pre-operative radiographs and
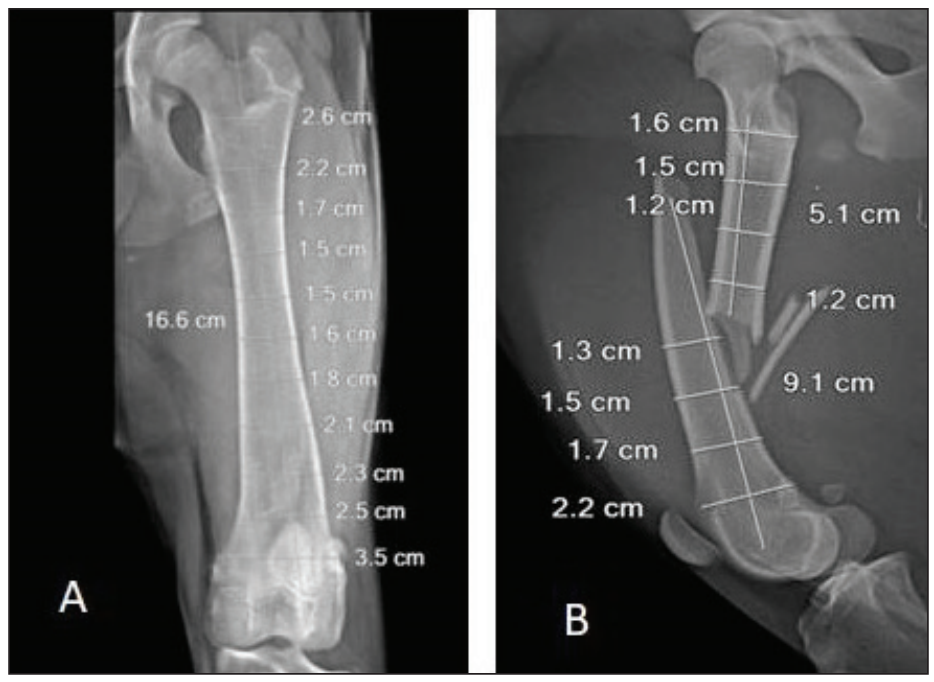

Fig. 3: Skiagram positioning for measurements for assessment of implants using electronic callipers. (A) Medio-lateral thickness of femur at different distances in contra lateral limb in antero-posterior view, (B) Cranio-caudal thickness of femur measuring the thickness of intrameduallary cavity in fracture limb in medio- lateral view 
Table 3: Post operative details of lameness grading

\begin{tabular}{llllllll}
\hline $\begin{array}{l}\text { Case. } \\
\text { No }\end{array}$ & \multirow{2}{*}{ Pre-operative } & \multicolumn{4}{c}{ Post-operative weight bearing at the end of } & Complete weight bearing \\
\cline { 3 - 6 } & & Day 1 & Day 15 & Day 30 & Day 60 & Day 90 & seen on \\
\hline 1 & V & III & II & I & I & I & $3^{\text {rd }}$ day \\
2 & V & IV & III & II & I & I & $15^{\text {th }}$ day \\
3 & V & III & III & II & I & I & $15^{\text {th }}$ day \\
4 & V & III & II & I & I & I & $10^{\text {th }}$ day \\
5 & V & IV & IV & III & II & I & $30^{\text {th }}$ day \\
6 & V & III & II & I & I & I & $15^{\text {th }}$ day \\
7 & V & III & II & I & I & I & $3^{\text {rd }}$ day \\
8 & V & III & II & I & I & I & $3^{\text {rd } d a y ~}$ \\
\hline & $5.00 \pm 0.00$ & $3.25 \pm 0.16$ & $2.50 \pm 0.26$ & $1.50 \pm 0.26$ & $1.12 \pm 0.12$ & $1.00 \pm 0.00$ & $11.75 \pm 3.26$ \\
\hline
\end{tabular}

Grade I- Normal weight bearing on all limbs at rest and while walking; Grade II- Normal weight bearing at rest, favors affected limb while walking; Grade III- Partial weight bearing at rest and while walking; Grade IV- Partial weight bearing at rest; does not bear weight on affected limb while walking; Grade V- Does not bear weight on limb at rest or while walking.
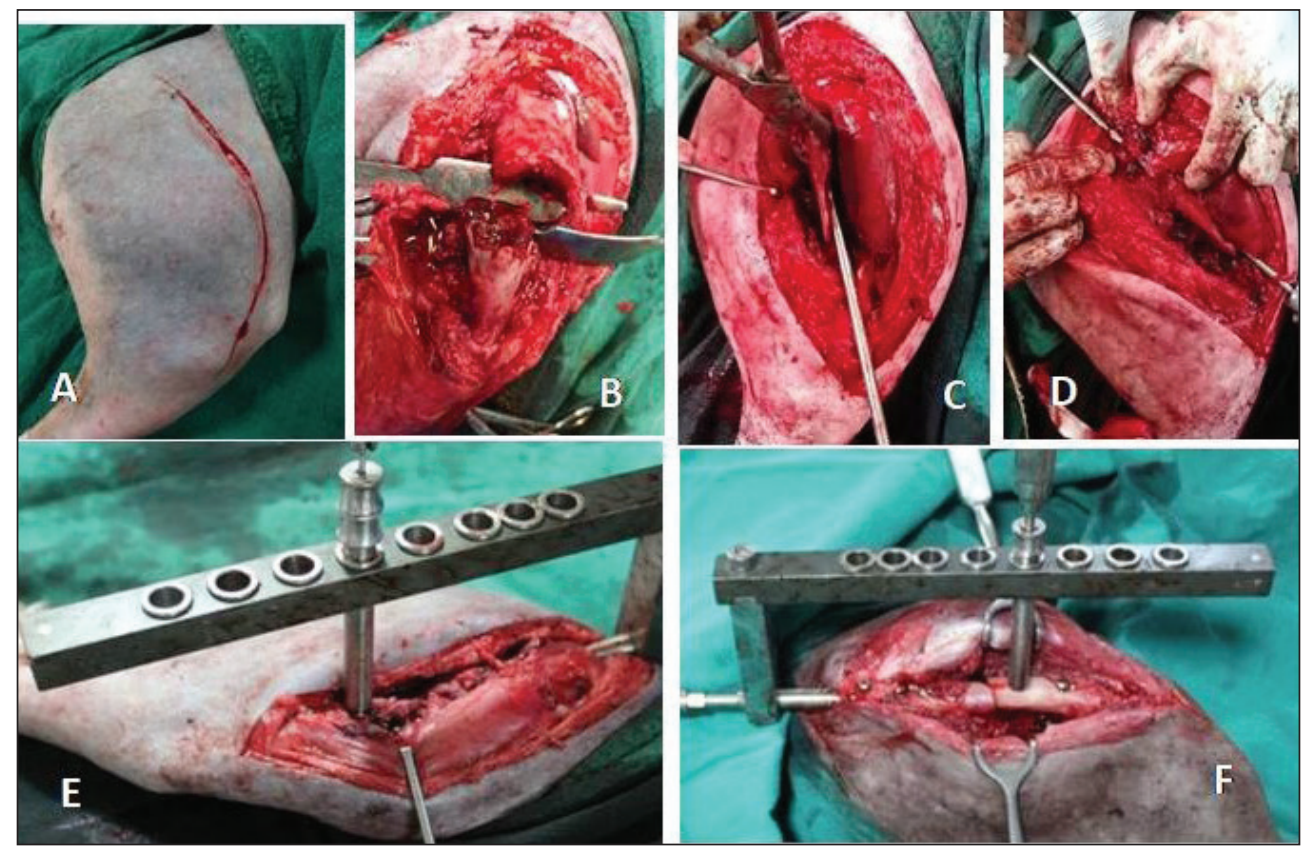

Fig. 4: Surgical procedure for titanium intramedullary interlocking nailing in femur fractures in dogs

(A) Skin incision made from trochanter major to lateral condyle of femur, (B) Femoral fractured fragments were exposed, (C) Retrograde insertion of steinmann pin in proximal fractured fragment, (D) The titanium intramedullary interlocking nail temporarily fixed to the trocar tip of the Steinmann pin (guide pin) for pushing into the marrow cavity, (E) After apposition of bony fragments drilling bone using appropriate drill bit through drill sleeve, (F) Transfixing of bolt using screw driver through screw driver sleeve.

type of fracture. The titanium intramedullary interlocking nail (IILN) of $5 \mathrm{~mm}, 6 \mathrm{~mm}, 7 \mathrm{~mm}$ and $8 \mathrm{~mm}$ thickness with length ranging from $140 \mathrm{~mm} 160 \mathrm{~mm}$ and $180 \mathrm{~mm}$ with titanium bolts ranging from $15 \mathrm{~mm}, 20 \mathrm{~mm}, 25 \mathrm{~mm}$, and $30 \mathrm{~mm}$ were used. The design of study is given in table 3 .

\section{Surgical procedure}

The cranio-lateral border of thigh approach was used for exposure of fractured diaphysis region of femur bone to perform titanium intramedullary interlocking nailing (Fig. 4A) (Piermattei and Johnson, 2014). Following the surgical 
exposure of the fracture site (Fig. 4B) as described, the fracture fragments were aligned and reduced to restore the length and correct rotational orientation.

Interlocking nail with $5 \mathrm{~mm}, 6 \mathrm{~mm}$ and $7 \mathrm{~mm}$ thickness had holes of $3.0 \mathrm{~mm}$ diameter. Whereas $8 \mathrm{~mm}$ thickness interlocking nail had $4.5 \mathrm{~mm}$ holes. The proximal end of interlocking nail had a positive threading. This threading facilitated anchoring with the negative threading of insertion and extraction rod of the jig. Two parallel depressed flat surfaces of $3.0 \mathrm{~mm}$ length are provided just below positive threading of interlocking nail. These flat surfaces helped in snug fixation of interlocking nail in the jig, prevented rotation and provided perfect alignment of screw holes of interlocking nail with the jig holes during operative procedure. The distal end had a depression which provided contact guidance for the interlocking nail over steinmann pin.

Drill bit of $2.00 \mathrm{~mm}$ diameter was used for $3.0 \mathrm{~mm}$ bolts and $3.5 \mathrm{~mm}$ diameter was used for $4.5 \mathrm{~mm}$ bolts The length of drill bit was $200 \mathrm{~mm}$. The diameter of the nail used was 70 to 90 per cent of the bone's diaphyseal diameter at isthmus. An opening in to the medullary cavity by using a Steinmen pin drilled through the proximal fragment in a retrograde manner from the fracture site (Fig. 4C). The standard veterinary interlocking nail was modified by making a depression at the distal end for temporary fixing with the trocar tip of Steinmann pin and for easy insertion into the medullary cavity.

The depression made in the distal end of the nail was temporarily fixed to the trocar tip of the steinmann pin (guide pin) (Fig. 4D). Then the nail was inserted in to the medullary cavity of the proximal fragment through the trochanteric fossa after attachment with the jig and inserting and extracting rod. As the nail was driven in to the medullary cavity of the proximal fragment the steinmann pin was withdrawn simultaneously. The fracture was reduced and once the apposition of the bony fragments was confirmed the nail was driven in to the distal fragment to get seated in the metaphyseal cancellous bone. Hammering was done in some cases using the inbuilt ram attached to inserting rod.

After the nail was properly seated, the trocar was inserted in to the appropriate hole in the jig to create a starting point so that drill bit would not slip while drilling. The drill guide and the appropriately sized drill bit were inserted into the same hole in the aiming device. Hole was drilled with the drill bit passing through the cis cortex, nail and trans cortex (Fig 4E). Appropriate length screw was transfixed to the nail. The transfixing of screw was done under the guidance of screw driver sleeve with the help of hexagonal tipped screw driver (Fig. 4F).

\section{Closure of the incision}

In case of femoral approach, the fascia lata was sutured with 2-0 polyglactin 910 in a simple continuous suture pattern. Subcuticular sutures were applied with 2-0 polyglactin 910. Skin incision was closed with a row of cruciate mattress sutures of 2-0 polyamide.

\section{Post-operative care and management}

The suture line was covered with a thin layer of sterile gauze bandage dipped in $5 \%$ povidone iodine solution, and covered with cotton padding and applied gauge bandage. Injection ceftriaxone sodium was administered at the rate of $25 \mathrm{mg} / \mathrm{kg}$ body weight as intramuscular injection for 7 days post-operatively. Injection meloxicam was administered once a day at the rate of $0.3 \mathrm{mg} / \mathrm{kg}$ body weight by intramuscular injection for 3 days postoperatively.

\section{RESULTS AND DISCUSSION}

Clinical evaluation was carried out every alternate day to check for the presence of swelling, exudation and weight bearing in all the dogs. The appearance of suture line was also examined every alternate day until the sutures were removed. The post- operative day on which the dog started bearing weight was recorded and graded.

\section{Post-Operative clinical observations}

None of the dogs developed post-operative swelling and suture dehiscence and the surgical wounds healed well in all the dogs without any complications.

\section{Lameness grading}

All eight dogs showed normal weight bearing at rest, the weight bearing of the affected limb while walking from $3^{\text {rd }}$ day in three dogs, $10^{\text {th }}$ day in two dogs, $15^{\text {th }}$ day in two 
dogs, $30^{\text {th }}$ day in one dog post-operatively. All eight dogs achieved complete weight bearing. The mean lameness grades observed pre-operatively and on $1^{\text {st }}$ day, $15^{\text {th }}$ day, $30^{\text {th }}$ day, $60^{\text {th }}$ day and $90^{\text {th }}$ day post-operatively were found to be $5.00 \pm 0.00,3.25 \pm 0.16,2.50 \pm 0.26,1.50 \pm 0.26$, $1.12 \pm 0.12$ and $1.00 \pm 0.00$, respectively. The mean age of the group to bear the complete weight on the affected limb were seen on $11.75 \pm 3.26$ days. Different post-operative weight bearing of the affected limb in all eight dogs were depicted in Fig. 5. The details of lameness grading (Vasseur et al., 1995) were presented in Table 4. Post-operatively, lameness grading showed gradual improvement to normal weight bearing over the period of study. The lameness grade was carried out in accordance with the protocol developed by Vasseur et al. (1995). After stabilization, five dogs progressed to grade I lameness by the end of $30^{\text {th }}$ post-operative day, and two dogs progressed to grade I by the end of $60^{\text {th }}$ post-operative day and one dog progressed to grade I on $90^{\text {th }}$ post-operative day. These results shows most of the dogs got early weight bearing and these finding was in agreement with the findings of Durall and Diaz (1996), Endo et al. (1998), McLaughlin (1999), Duhautois (2003), Parthiban (2004), Díaz et al.(2005), Giordano et al. (2006), Yadav et al. (2006), and Bellon and Mullon (2011). Also, Singh et al. (2007) reported early weight bearing and quick rehabilitation, attributed to adequate stability provided by the static intramedullary interlocking nailing.

Table 4: Clinical details of dogs (Titanium Intramedullary Interlocking Nailing Technique)

\begin{tabular}{|c|c|c|c|c|c|c|c|c|}
\hline $\begin{array}{l}\text { Sl. } \\
\text { No. }\end{array}$ & $\begin{array}{l}\text { Breed of } \\
\text { dog }\end{array}$ & Sex & Age & $\begin{array}{l}\text { Etiology of } \\
\text { fracture }\end{array}$ & $\begin{array}{l}\text { Unilateral / } \\
\text { bilateral }\end{array}$ & $\begin{array}{l}\text { Type of } \\
\text { fracture }\end{array}$ & $\begin{array}{l}\text { Details of implant } \\
\text { used }\end{array}$ & No of bolts used \\
\hline 1 & $\begin{array}{l}\text { German } \\
\text { Shepherd }\end{array}$ & Male & $\begin{array}{l}4 \\
\text { months }\end{array}$ & Car accident & $\begin{array}{l}\text { Unilateral right } \\
\text { femur }\end{array}$ & $\begin{array}{l}\text { Oblique } \\
\text { diaphyseal } \\
\text { fracture } \\
\end{array}$ & $\begin{array}{l}\text { Titanium IILN } 7 \\
\text { mm thickness } 140 \\
\text { mm length }\end{array}$ & $\begin{array}{l}5 \text { titanium bolts ( } 3 \text { proximal } \\
\text { and } 2 \text { distal, } 3 \mathrm{~mm} \text { diameter, } \\
\text { length } 25 \mathrm{~mm}^{-3}, 20 \mathrm{~mm}^{-2} \text { ) }\end{array}$ \\
\hline 2 & Mongrel & Male & 8 months & Car accident & $\begin{array}{l}\text { Unilateral right } \\
\text { femur }\end{array}$ & $\begin{array}{l}\text { Spiral } \\
\text { diaphyseal } \\
\text { fracture }\end{array}$ & $\begin{array}{l}\text { Titanium IILN } 6 \\
\text { mm thickness } \\
140 \text { mm length }\end{array}$ & $\begin{array}{l}4 \text { Titanium bolts ( } 2 \text { proximal } \\
\text { and } 2 \text { distal, } 3 \mathrm{~mm} \text { diameter, } \\
\text { length } 30 \mathrm{~mm}^{-2} 25 \mathrm{~mm}^{-2} \text { ) }\end{array}$ \\
\hline 3 & Mongrel & Female & $\begin{array}{l}4 \\
\text { months }\end{array}$ & Bike accident & $\begin{array}{l}\text { Unilateral right } \\
\text { femur }\end{array}$ & $\begin{array}{l}\text { Comminuted } \\
\text { diaphyseal } \\
\text { fracture }\end{array}$ & $\begin{array}{l}\text { Titanium IILN } \\
5 \mathrm{~mm} \text { thickness } \\
160 \mathrm{~mm} \text { length }\end{array}$ & $\begin{array}{l}4 \text { titanium bolts ( } 2 \text { proximal } \\
\text { and } 2 \text { distal, } 3 \mathrm{~mm} \text { diameter, } \\
\text { length } 25 \mathrm{~mm}^{-2}, 20 \mathrm{~mm}^{-2} \text { ) }\end{array}$ \\
\hline 4 & Mongrel & Female & 5 months & Bike accident & $\begin{array}{l}\text { Unilateral right } \\
\text { femur }\end{array}$ & $\begin{array}{l}\text { Oblique } \\
\text { diaphyseal } \\
\text { fracture }\end{array}$ & $\begin{array}{l}\text { Titanium IILN } 6 \\
\text { mm thickness } \\
140 \text { mm length }\end{array}$ & $\begin{array}{l}3 \text { Titanium bolts ( } 2 \text { proximal } \\
\text { one distal, } 3 \mathrm{~mm} \text { diameter, } \\
20 \mathrm{~mm}^{-2}, 15 \mathrm{~mm}^{-1} \text { ) }\end{array}$ \\
\hline 5 & $\begin{array}{l}\text { Golden } \\
\text { Retriever }\end{array}$ & Male & 7 months & $\begin{array}{l}\text { Slipped on the } \\
\text { floor }\end{array}$ & $\begin{array}{l}\text { Unilateral right } \\
\text { femur }\end{array}$ & \begin{tabular}{|l} 
Spiral \\
diaphyseal \\
fracture \\
\end{tabular} & $\begin{array}{l}\text { Titanium IILN } 6 \\
\text { mm thickness } 180 \\
\text { mm length }\end{array}$ & $\begin{array}{l}4 \text { Titanium bolts ( } 2 \text { proximal } \\
\text { and two distal bolts, } 3 \mathrm{~mm} \\
\text { diameter, length }-25 \mathrm{~mm}^{-4} \text { ) }\end{array}$ \\
\hline 6 & $\begin{array}{l}\text { German } \\
\text { Shepherd }\end{array}$ & Male & 6 months & $\begin{array}{l}\text { Slipped on the } \\
\text { floor }\end{array}$ & $\begin{array}{l}\text { Unilateral right } \\
\text { femur }\end{array}$ & $\begin{array}{l}\text { Oblique } \\
\text { diaphyseal } \\
\text { fracture }\end{array}$ & $\begin{array}{l}\text { Titanium IILN } 8 \\
\text { mm thickness } 160 \\
\text { mm length }\end{array}$ & $\begin{array}{l}5 \text { titanium bolts ( } 2 \text { proximal } \\
\text { and } 3 \text { distal bolts, } 4.5 \mathrm{~mm} \\
\text { diameter, length } 30 \mathrm{~mm}^{-1}, 25 \\
\left.\mathrm{~mm}^{-3}, 20 \mathrm{~mm}^{-1}\right)\end{array}$ \\
\hline 7 & Mongrel & Female & $\begin{array}{l}12 \\
\text { months }\end{array}$ & Bike accident & $\begin{array}{l}\text { Unilateral right } \\
\text { femur }\end{array}$ & $\begin{array}{l}\text { Comminuted } \\
\text { oblique } \\
\text { diaphyseal } \\
\text { fracture }\end{array}$ & $\begin{array}{l}\text { Titanium ILLN } 6 \\
\text { mm thickness } 160 \\
\text { mm length }\end{array}$ & $\begin{array}{l}4 \text { Titanium bolts ( } 2 \text { proximal } \\
\text { and } 2 \text { distal, } 3.0 \mathrm{~mm} \\
\text { diameter, length } 30 \mathrm{~mm}^{-2} 25 \\
\mathrm{~mm}^{-2} \text { ) }\end{array}$ \\
\hline \multirow[t]{2}{*}{8} & Mongrel & Male & $\begin{array}{l}12 \\
\text { months }\end{array}$ & Car accident & $\begin{array}{l}\text { Unilateral right } \\
\text { femur }\end{array}$ & $\begin{array}{l}\text { Spiral } \\
\text { diaphyseal } \\
\text { fracture }\end{array}$ & $\begin{array}{l}\text { Titanium ILLN } 6 \\
\text { mm thickness } 160 \\
\text { mm length }\end{array}$ & $\begin{array}{l}5 \text { titanium bolts ( } 2 \text { proximal } \\
\text { and } 3 \text { distal bolts, } 3.0 \mathrm{~mm} \\
\text { diameter, length } 30 \mathrm{~mm}^{-2}, 25 \\
\mathrm{~mm}^{-3} \text { ) }\end{array}$ \\
\hline & & $\begin{array}{l}\text { Males -5 } \\
\text { Females -3 }\end{array}$ & $\begin{array}{l}4 \text { to } 12 \\
\text { months }\end{array}$ & & $\begin{array}{l}\text { Unilateral right } \\
\text { femur fractures- } 8\end{array}$ & & & \\
\hline
\end{tabular}



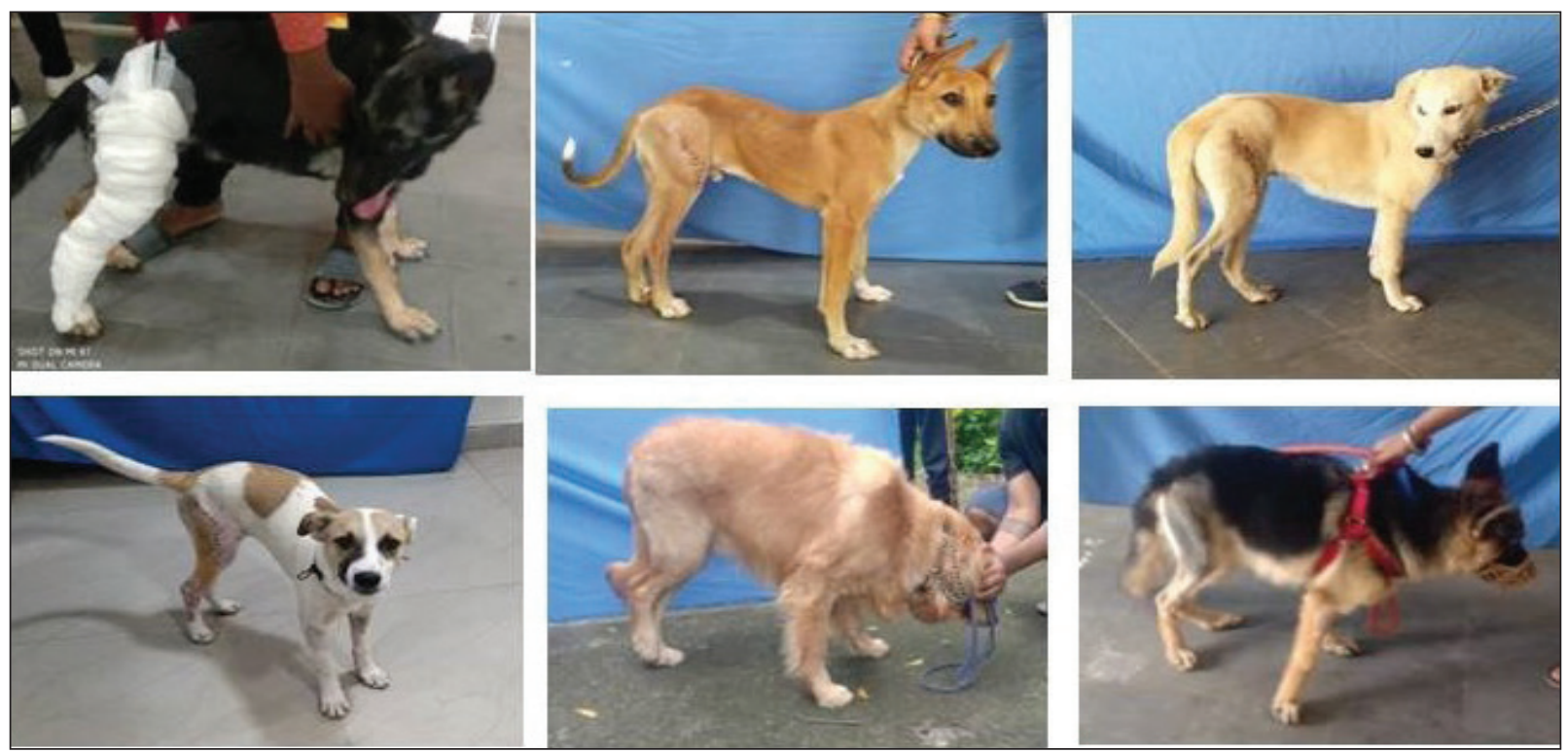

Fig. 5: Showing first weight bearing of affected hind limb on different post-operative days in all dogs

Table 5: Details of Radiological scoring in all dogs in this group

\begin{tabular}{|c|c|c|c|c|c|c|c|c|c|c|c|c|}
\hline \multirow[b]{2}{*}{$\begin{array}{c}\text { Case } \\
\text { No. }\end{array}$} & \multicolumn{3}{|c|}{ Day 0} & \multicolumn{3}{|c|}{$30^{\text {th }}$ Day } & \multicolumn{3}{|c|}{ 60 $^{\text {th }}$ Day } & \multicolumn{3}{|c|}{ 90 ${ }^{\text {th }}$ Day } \\
\hline & 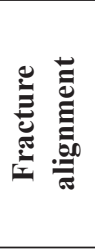 & 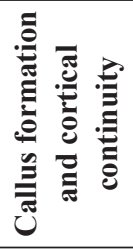 & 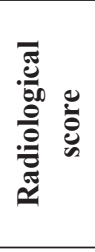 & 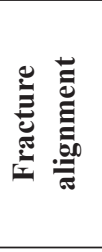 & 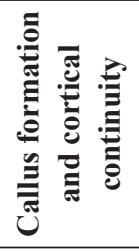 & 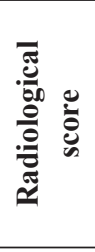 & 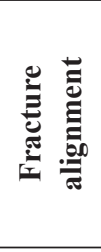 & 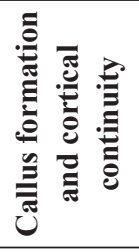 & 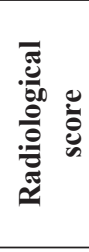 & 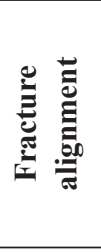 & 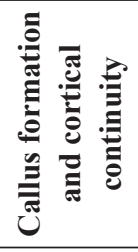 & 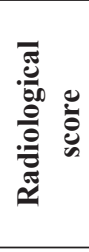 \\
\hline & \multicolumn{12}{|c|}{ Titanium intramedullary interlocking nailing technique } \\
\hline 1 & + & - & 3 & + & +++ & 1 & + & +++ & 1 & + & +++ & 0 \\
\hline 2 & + & - & 3 & + & +++ & 1 & + & +++ & 1 & + & +++ & 0 \\
\hline 3 & + & - & 3 & + & +++ & 1 & + & +++ & 1 & + & +++ & 0 \\
\hline 4 & + & - & 3 & + & +++ & 1 & + & +++ & 1 & + & +++ & 0 \\
\hline 5 & + & - & 3 & + & + & 1 & + & ++ & 1 & + & ++ & 1 \\
\hline 6 & + & - & 3 & + & +++ & 1 & + & +++ & 0 & + & +++ & 0 \\
\hline 7 & + & - & 3 & + & +++ & 1 & + & +++ & 1 & + & +++ & 0 \\
\hline 8 & + & - & 3 & + & +++ & 1 & + & +++ & 1 & + & +++ & 0 \\
\hline
\end{tabular}

Fracture alignment- '+' fracture fragments align in anatomical position, '-' fracture fragments not in anatomical position; Callus formation and cortical continuity- ' +++ ' Good callus, '++' Moderate callus, '+' Poor callus; Radiological score (Cook et al., 1999) : '0'- complete radiiogaphic healing, '1'-Appropriate progression towards healing, but not completely healed, '2'-Inappropriate progression towards healing, ' 3 '- No evidence of healing, failure.

\section{Post-operative radiographic observations}

Immediate Post-operative radiographic evaluation confirmed proper placement of Titanium intramedullary interlocking nail with proximal and distal titanium bolts and good apposition of the fractures fragments in all dogs.
An additional cerclage wiring was applied in two dogs along with Titanium interlocking nail to immobilize the large wedge fracture fragments. The radiographs obtained on the $15^{\text {th }}$ post-operative day revealed proper apposition and alignment of fracture fragments in all the eight dogs. 
The radiographs obtained on the $30^{\text {th }}$ post-operative day in all dogs showed evidence of callus formation. By $60^{\text {th }}$ day, in two dogs, bridging callus formation, and in other 6 dogs the fracture line disappeared showing clear restitution of cortico-medullary cavity. In Case 4 the bolt loosening was evident due to over activeness of the dog, however, complete cortico-medullary continuity is seen. The radiographs obtained on the $90^{\text {th }}$ post-operative day clearly shows complete formation of bone with distinct cortico-medullary distinction at the fracture site except that in one dog, it is still in the process of formation of the bone however, the dog was putting complete weight on the affected limb. The progressive radiographic fracture healing was showed in Fig. 6. In this it is depicted that 7 dogs had fast healing, one dog had slow healing without any complications, except that bolt loosening and breakage in one dog each (Diaz et al., 2005). In comparison, there was clinical evidence that titanium implants have a lower rate of failure and fewer complications than similar stainless steel implants (Barber et al., 2021) and details of Radiological scoring (Cook et al., 1999) in all dogs were shown in table 5. This is in congruence with Igna et al. (2011), African et al. (2017). The use of Cerclage wire with Ti IILN for complete anatomic reduction in two dogs is in congruence with Cross et al. (2004) and Kurum (2012).

The radiographs obtained on the $15^{\text {th }}$ to $90^{\text {th }}$ post-operative day clearly shows complete formation of bone with distinct cortico-medullary distinction at the fracture site except that in one dog, it is still in the process of formation of the bone however, the dog is putting complete weight on the affected limb. Radiographically it is depicted that 7 dogs had fast healing, one dog had slow healing. The results of this group of dogs was in congruence with several other workers (Parthiban, 2004; Stiffler, 2004; Haaland et al., 2009; Asif et al., 2010; Igna et al., 2011; Raghunath et al., 2012; African et al. (2017) and Stigen (1999) repaired supracondylar femoral fractures with interlocking nailing technique. Whereas while others results differed with malunion, unscrewing Diaz et al. (2005), and "windshieldwiper effect" and screw bending observed by Diaz et al. (2003).

In dogs, with titanium intramedullary interlocking nailing technique, out of eight dogs, two dogs with femur fracture showed titanium bolt loosening on $90^{\text {th }}$ post-operative day and one dog had break in distal bolt, this was in accordance with Dueland et al. (1997). However, the dogs had complete functional limb usage on $60^{\text {th }}$ postoperative day. Loosening of one proximal titanium bolt in dog due to its aggressiveness and loosening of one distal bolt in another dog is due to its jumping from height after $60^{\text {th }}$ day, resulting in angulation in callus formation at the fracture site. These findings were in agreement with the findings of Durall and Diaz (1996), Roush and McLaughlin (1999), Suber et al. (2002), Duhautois (2003), Wheeler et al. (2004), Bhat et al. (2006), Patel et
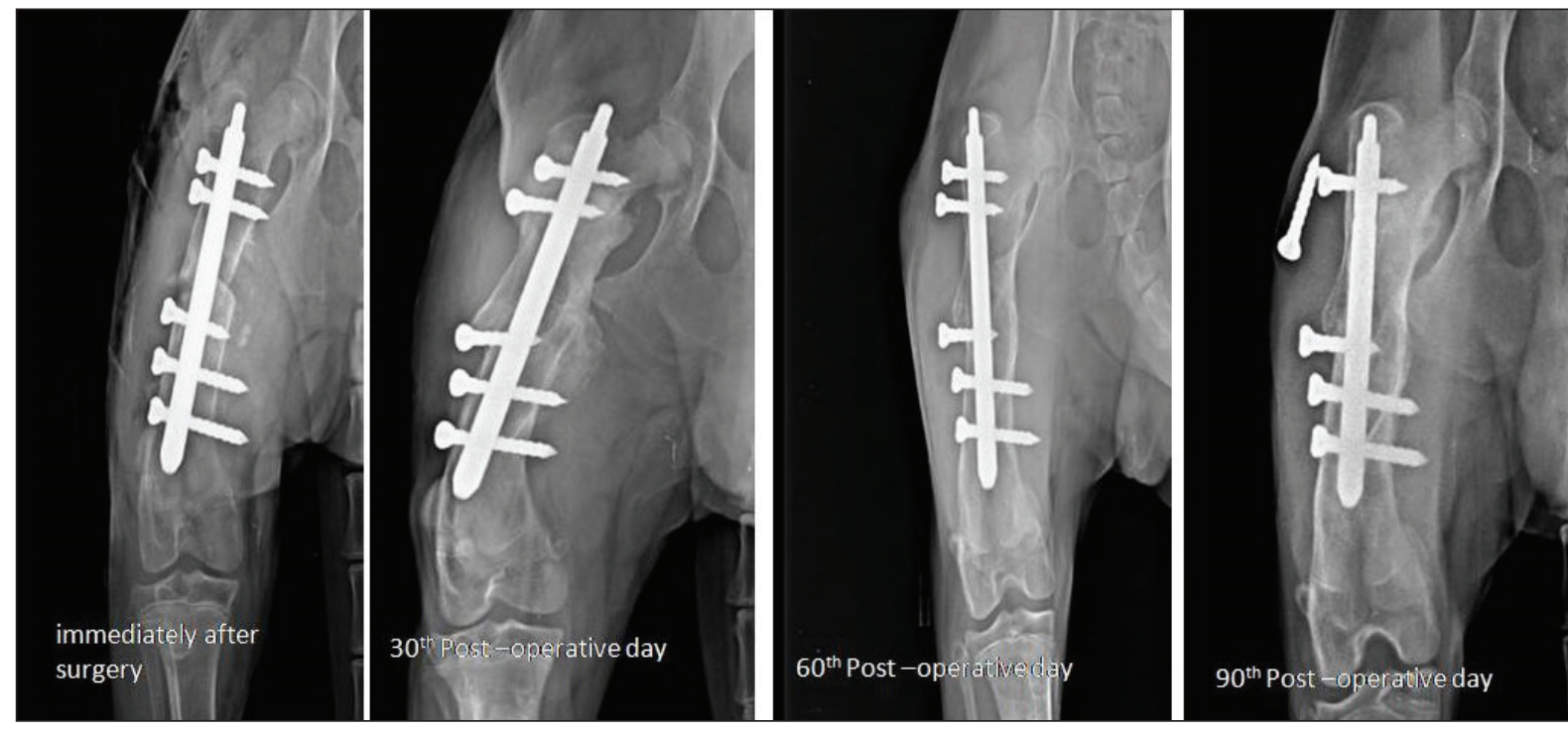

Fig. 6: Skiagram showing progressive radiographic fracture healing in different time periods 
al. (2007) and Raghunath and Singh (2008) where they listed post-operative complications like angulations of the bone, loosening of screws, and locking mistakes. Also, Ikem et al. (2007) reported that loosening of screw was due to severe osteoporosis of bone, and delayed union and superficial wound infection was other complications. Whereas in contrary to our results, Somogyvari et al. (1981) reported that fixation was unstable owing to loose fitting of the pins and bolts, healing was delayed and pseudoarthrosis occurred.

\section{CONCLUSION}

Based on present study, it was concluded that Titanium intramedullary interlocking nailing (Ti-IILN) was successful for the repair of communited diaphyseal femur fractures in dogs with lower rate of failure and fewer complications and offered early return of limb function, with good fracture stability till the completion of the bone healing in all dogs when compared to stainless steel IILN. The application of Ti- IILN was found to be effective with additional features compared with stainless steel such as excellent biocompatibility, high strength-to-weight ratio, lower elastic modulus, and superior corrosion resistance.

\section{REFERENCES}

African, M., Alkan, F., Altan, S., Parlak, K. and Yavru, N. 2017. Clinical Experience of Interlocking Nail Stabilization of Long Bone Fractures in Dogs - A Retrospective Study of 26 Cases. Isr. J. Vet. Med., 72(2): 45-50.

Arens, S., Schlegel, U., Printzen, G., Ziegler, W .J., Perren, S.M. and Hansis, M. 1996 Influence of materials for fixation implants on local infection: An experimental study of steel versus titanium DCP in rabbits. British Editorial Soc. Bone Joint Surgery, 78(B): 647-651.

Asif, M.A., Dilipkumar, D., Usturge, S.M., Shivaprakash, B.V., Vivek, R. Kasaralikar and Raidurg, R. 2010. Comparative evaluation of static and dynamic veterinary intramedullary interlocking nailing technique for femoral fractures in canines. Vet. Pract., 11(2): 146-150.

Bellon, J. and Mulon, P.Y. 2011. Use of a novel intramedullary nail for femoral fracture repair in calves: 25 cases (20082009). J. Am. Vet. Med. Asso., 238(11): 1490-1496

Bhat, A.K., Rao, S.K. and Bhaskaranand, K. 2006. Mechanical failure in intramedullary interlocking nails. J. Orthop. Surg., 14(2): $138-141$.

Barber, C.C., Burnham, M., Ojameruaye, O. and McKee, M.D.
2021. A systematic review of the use of titanium versus stainless steel implants for fracture fixation: Ortho. Trau. Asso. Int., e138.

Cook, J.L., Tomlinson, J.L. and Reed, A.L. 1999. Fluroscopically guided closed reduction and internal fixation of fractures of the lateral portion of the humeral condyle: prospective clinical study of the technique and result in ten dogs. Vet. Surg., 28: 315- 321.

Cross, A.R., Lewis, D.D., Parker, R.B., Stubbs, W.P. and Wheeler, J.L. 2004. Intramedullary interlocking nail fixation in dogs and cats: clinical applications. Comp. Cont. Educ. Pract., 26(7): 531-543.

Durall, I. and Diaz, M.C. 1996. Early experience with the use of an interlocking nail for the repair of canine femoral shaft fractures. Vet. Surg., 25: 397-406.

Diaz, M.C., Durall, I., Franch, J., Puchol, J.L. and Sanchez, A. 2005. Interlocking nail treatment of long-bone fractures in cats: 33 cases (1995-2004). Vet. Comp. Orthop. Traumatol., 18(3): 119-126.

Diaz, M.C., Durall, I., Franch, J. and Puchol, J.L. 2003. Radiographic findings related to interlocking nailing: windshield-wiper effect, and locking screw failure. Vet. Comp. Orthop. Traumatol., 16(4): 217-222.

Dueland, R.T., Vanderby, R. and Mccabe, R.P. 1997. Fatigue study of six and eight $\mathrm{mm}$ diameter interlocking nails with screw holes of variable size and number. Vet. Comp. Orthop. Traumatol., 10: 194-199.

Duhautois, B. 2003. Use of veterinary interlocking nailing for diaphyseal fractures in dogs and cats: 121 cases. Vet. Surg., 32: $8-20$

Endo, K., Nakamura, K., Maeda, H. and Matsushita, T. 1998. Interlocking intramedullary nail method for the treatment of femoral and tibial fractures in cats and small dogs. J. Vet. Med. Sci., 60(1): 119-122.

Fattahian, H.R., Mohyeddin, H., Molookpour, H. and Hoseinzadeh, A.R. 2011. Retrospective study of surgical treatment of various patellar luxations in dogs from 2004 to 2007. Ir. J. Vet. Res., 12(1): 56-60.

Ferrell, M. 2016. Orthopaedic implants. In BSAVA Manual of Canine and Feline Fracture Repair and Management. British Small Animal Veterinary Association, Gloucester. Edn $2^{\text {nd }}$, pp. $72-87$.

Giordano, P.P., Padilha-filho, J.G. and Lolli-junior, J. 2006. Modified femoral interlocking nail. Experimental and clinical study in dogs. Ars-Veterinaria., 22(3): 184-191.

Guiot, L.P., Demianiuk, R.M. and Dejardin, L.M. 2012. Fractures of the femur. In Veterinary Surgery Small Animal, Vol. 1 edited by Karen M. Tobias and Spencer A. Johnston. 2012. Edn. 1 $1^{\text {st }}$, pp. $865-905$. 
Haaland, P.J., Sjostrom, L., Devor, M. and Haug, A. 2009. Appendicular fracture repair in dogs using the locking compression plate system: 47 cases. Vet. Comp. Orthop. Traumatol., 22(4): 309-315.

Igna, C., Schuszler, L., Dascalu, R., Sabau, M. and Luca, C. 2011. Interlocking Nail Stabilization of Diaphyseal LongBone Fractures. Initial Experiences in Six Clinical Cases. Bulletin UASVM, Vet. Med., 68(2): 165-170.

Ikem, I.C., Ogunlusi, J.D. and Ine, R.E. 2007. Achieving interlocking nails without using an image intensifier. Int. Orthop., 31: 487-490.

Keosengthong, A., Naruepon, K., Jitpean, S., Seesupa, S., Kunkitti, P. and Hoisang, S. 2019. Incidence and classification of bone fractures in dogs and cats: a retrospectivestudy at a Veterinary Teaching Hospital, Khon Kaen University, Thailand (2013-2016). Vet. Int. Sci., 17(2): 127-139.

Kürüm, B. 2012. Interlocking nail stabilization of canine femoral fractures; clinical experience and results of the nineteen cases. Kafkas Univ. Vet. Fak. Derg., 18(6): 1027-1034.

McLaughlin, R. 1999. Internal fixation - intramedullary pins, cerclage wires and interlocking nails. Vet. Clin. North Am. Small Anim. Pract., 29:1097-1115.

Nouri., A., Hodgson., Peter, D. and Wen, Cuie. 2010. Biomimetic porous titanium scaffolds for orthopaedic and dental applications. In Biomimetics learning from nature, InTech, Rijek, Croatia, pp. 415-450.

Parthiban, N. 2004. Efficacy of veterinary interlocking nail for the management of diaphyseal fractures of femur in dogs. M.V.Sc. Thesis, Tamil Nadu Veterinary and Animal Sciences University, Chennai, India.

Patel, B.M., Kelawala, N.H., Parikh, P.V., Patil, D.B., Gupta, P. and Tank, P.H. 2007. Interlocking nailing for repair of canine tibial shaft fracture under image intensifier. Indian J. Vet. Surg., 28(2): 123-124.

Patil, M., Desai, D., Shivaprakash, B., Kasaralikar, V., Ramesh, B. and Tikare, V. 2018. Prevalence of Fracture in Animals in Karnataka State: 4 Years Study. Inter. J. Livst. Res., 8(3): 196-205.

Piermattei, D.L. and Johnson, K.A. 2014. The hind limb in an atlas of surgical approaches to the bones and joints of the dog and cat. $5^{\text {th }}$ Ed. Saunders WB, Philadelphia. 369.
Raghunath, M., Bishnoi, A.K., Singh, S.S., Singh, M., Sharma, A. and Atri, K. 2012. Management of segmental fractures of tibia and femur by static intramedullary interlocking nailing in twelve days. Int. J. App. Res. Vet. Med., 10(3): 264-272.

Raghunath, M. and Singh, S.S. 2008. Intramedullary interlocking nailing for management of long bone diaphyseal fractures in dogs: a study of 17 clinical cases. Indian J. Vet. Surg., 29(2): 106-109.

Roush, J.K. and McLaughlin, R.M. 1999. Using interlocking nail fixation to repair fractures in small animals. Vet. Med., 94(1): 46-52

Singh, M., Yadav, R.K., Raghunath, M. and Singh, S.S. 2007. Repair of bilateral femur fracture with static intramedullary nailing in three dogs: a clinical report. Indian J. Vet. Surg., 28: $48-49$.

Somogyvari, K., Berentey, G., Kokeny, G., Feczko, J. and Sarvary, A. 1981. Interlocking medullary nailing, its effect on healing of the osteotomized bone. Acta Veterinaria Academiae Scientiarum Hungaricae., 29(3): 233-247

Stiffler, K.S. 2004. Internal fracture fixation. Clin. Tech. Small Anim. Pract., 19(3): 105-113.

Stigen, Q. 1999. Supracondylar femoral fracture in 15 dogs and cats treated using a normograde intramedullary pinning technique. J. Small Anim. Pract., 40: 519- 523.

Suber, J.T., Basinger, R.R. and Keller, W.G. 2002. Two unreported modes of interlocking nail failure: breakout and screw bending. Vet. Comp. Orthop. Traumatol., 15(4): 228232.

Vasseur, P.B., Johnson, A.L., Buderberg, S.C., Linwln, J.B., Toombs, J.P., Whitebain, J.G. and Lentz, E.L. 1995. Randomized, controlled trials of the efficacy of carprofen, a non-steroidal anti-inflammatory drug in the treatment of osteoarthritis in dogs. J. Am. Vet. Med. Assoc., 206: 807-81.

Wheeler, J.L., Lewis, D.D., Cross, A.R., Stubbs, W.P. and Parker, R.B. 2004. Intramedullary interlocking nail fixation in dogs and cats: clinical applications. Comp. Cont. Educ. Pract., 26(7): 531-543.

Yadav, R.K., Raghunath, M. and Singh, S.S. 2006. Static intramedullary interlocking nail for the management of complicated femoral fractures in dogs. Indian J. Vet. Surg., 27(2): 113-115. 
